\title{
The influence of employees' perceptions of organizational politics on turnover intentions in Zimbabwe's SME sector
}

\author{
R. Chinomona* \\ Department of Logistics Management, \\ Vaal University of Technology, Republic of South Africa \\ rchinos@hotmail.com \\ E. Chinomona \\ Department of Human Resources Management, \\ Vaal University of Technology, Republic of South Africa
}

\begin{abstract}
Despite increasing awareness of the importance of managing the negative effects of organizational politics at the workplace, research on consequences relating to employees' perceptions of the same in small and medium enterprises (SMEs) in Africa has received little attention. Therefore, using data from 250 SMEs in Zimbabwe, this study examines the effects of employees' perceptions of organizational politics on turnover intentions and the mediating influence of employees' perceptions of equity and organizational commitment. All the posited six hypotheses were supported by the sample data. Managerial implications of the findings are discussed and limitations and future research directions are indicated.
\end{abstract}

*To whom all correspondence should be addressed.

\section{Introduction}

Organizational politics has intrigued academicians and practitioners for decades. Yet, serious scholarship on politics in organizations has emerged as a viable body of scientific inquiry just within the past twenty years (Ferris, Adams, Kolodinsky, Hochwarter \& Ammeter, 2002; Drory \& Vigoda-Gadot, 2010). Studies have long argued that politics is an epidemic phenomenon ubiquitous in organizations and that it deserves more attention and empirical examination (e.g., Vigoda, 2000; Pfeffer, 1992; Andrews, Witt \& Kacmar, 2003). The importance of organizational politics (OP) lies in its potential negative consequences and effects on work outcomes. Accumulating empirical research has provided considerable evidence that organizational politics among others breeds negative perception of equity, diminish organizational commitment and eventually necessitates turnover intentions or turnover (see Ferris et al., 2002 and Rosen, Chang, Johnson and Levy, 2009). Moreover, the current received wisdom is that turnover intentions or turnover should be reduced or avoided by organizations since it is more costly to replace an employee than to retain one (Carson \& Gilmore, 2000). In view of that, research interests on the effects of organizational politics on turnover intentions are quite substantial and growing (Andrews et al., 2003). Regrettably, these studies are focused on large size firms and with little regard to the small and medium enterprises (SMEs) sector.
Given that the SMEs sector is regarded as the engine of economic growth and major instrument for employment generation in both developed and developing countries (Chinomona, Lin, Wang \& Cheng, 2010), it is surprising that, this important matter in such a vital sector has been largely neglected by researchers. More so, the charecteristics of the large sized firms and the SMEs are different (Sieger, Bernard \& Frey, 2011) and therefore, the findings might be expected to be different. Besides, these prior studies on large firms have been largely from developed countries (Chinomona \& Pretorius, 2011) and thus, given the uniqueness of developing countries from Africa such as Zimbabwe, the results may be different. By and large, perhaps research focused on the effects of employees' perceptions of organizational politics on turnover intentions in the context of SMEs in Africa is long overdue and imperative to undertake.

The present study seeks to address the aforementioned gap in literature; hence the focal purpose of this research is three-fold. Firstly, from the perspective of employees in the SMEs sector, this research mainly seeks to investigate the extent to which perceptions of organizational politics directly influence their turnover intentions in Zimbabwe. Secondly, the current study also seeks to explore the mediating influence of employees' perceptions of equity and organizational commitment in this relationship. Thirdly, an attempt is made to apply the justice judgment theory in this research context. This endeavor is considered to provide a strong theoretical grounding to the current research. On the 
whole, the findings of this study are expected to contribute new knowledge to the existing body of human resources management literature on organization politics effects on turnover intentions, as well as providing practical implications to practitioners in the SMEs sector, particularly in the context of developing countries in Africa.

The remaining sections of this article will provide a literature review, propose a conceptual research model and develop the research hypotheses, provide the research methodology, analyze data and present results. Finally, results are discussed, implications provided and limitations and future research directions highlighted.

\section{Justice judgement theory}

The study of justice or fairness has been a topic of philosophical interests that extend back to as far as Plato and Socrates (Colquitt et al., 2001). Research consistently finds that people care about fair treatment. When individuals perceive that they are treated fairly, they express greater satisfaction with social relationships (Warner, Hegtvedt \& Roman, 2005). A proliferation of studies in organizational justice suggests that Justice Judgment theory assumes that an individual's perception of fairness is based on justice rules (Colquitt et al., 2001; Walumbwa, Cropanzano \& Hartnell, 2009). Justice rule is defined as an individual's belief that a distribution of outcome, or procedure for distribution of outcomes, is fair and appropriate when it satisfies certain criteria (Sieger et al., 2011). This definition presupposes two categories of justice rules, namely distribution rules and procedural rules.

A distribution rule is defined as an individual's belief that it is fair and appropriate when rewards, punishments, or resources are distributed in accordance with certain criteria (Colquitt et al., 2001; Walumbwa et al., 2009). A specific criterion might require the matching of rewards to contributions, or matching rewards to needs or dividing rewards equally. Thus, a contributions rule, needs rule and equality rule are among the major distributive rules that can influence an individual's perception of distributive fairness (Warner et al., 2005).

A procedural rule is defined as an individual's belief that allocative procedures which satisfy certain criteria are fair and appropriate (Walumbwa et al., 2009). Every group, organization or society has procedures that regulate the distribution of rewards and resources. There is a network of regulatory procedures that guides the allocative process. The concept of procedural fairness refers to an individual's perception of the fairness of procedural component of the social system that regulates the allocative process (Sieger $e t$ al., 2011). An individual uses justice rules to evaluate the fairness of allocative procedures (Ferris et al., 2002). Thus in this case justice rule is viewed as a belief that allocative procedures are fair when they satisfy certain criteria. Six procedural justice rules are postulated that define criteria which allocative procedures must satisfy to be perceived as fair. These are the consistency rule, bias-suppression rule, accuracy rule, correctability rule, representativeness rule and ethicality rule (Colquitt et al., 2001).

While the presence of distributive or procedural justice in an organization makes employees anticipate equity at their workplace, be committed to the organization and reduce inclination towards turnover intentions (Loi, Hang-yue \& Foley, 2006) organizational politics mostly goes against the spirit of justice theory. In a politically charged organization, employees feel insecure because of high job ambiguities, unfairness, unjust treatment and perceived inequity (Lind, 2001). For instance, where perceived inequity is high, employees are likely to be dissatisfied and consequently, this lead to low organizational commitment and high turnover intentions or ultimately job quit (Lowe \& Vodanovich, 1995; Loi et al., 2006). On the contrary, the absence of negative organizational politicking might create a just and fair working environment that makes employees have a perception of equity, which might culminate in high organizational commitment and low turnover intentions (Sieger et al., 2011). Drawing from these aforementioned assertions a conceptual model in Figure 1 is developed.

\section{Conceptual research model}

In this conceptual model, employee perception of organizational politics is the sole predictor, directly influencing turnover intentions, employee perceptions of equity and organizational commitment. Employee perceptions of equity and organizational commitment are mediators while employee turnover intentions is the outcome variable.

\section{Hypothesis development}

\section{Employee perception of organizational politics and employee turnover intention}

Given that people tend to view organizational politics as undesirable because of the unfair and unjust perceptions and treatment associated with it at workplace environment, they are unlikely to stay permanently in a politically charged organization (Ferris et al., 2002). It follows therefore, in concurrence to justice judgment theory that as a result of high organizational politics perceived in the form of unfair and unjust treatment, employees will likely choose to withdraw physically or psychologically from their jobs. One physical form of withdrawal is to quit the job. Not all employees, however, have the immediate luxury of such an option. The likely short-term option for those with less job mobility is psychological withdrawal, such as intentions to quit the job. Ferris and Kacmar (1992) showed that organizational politics cause inefficiency and ineffectiveness in organizations. 


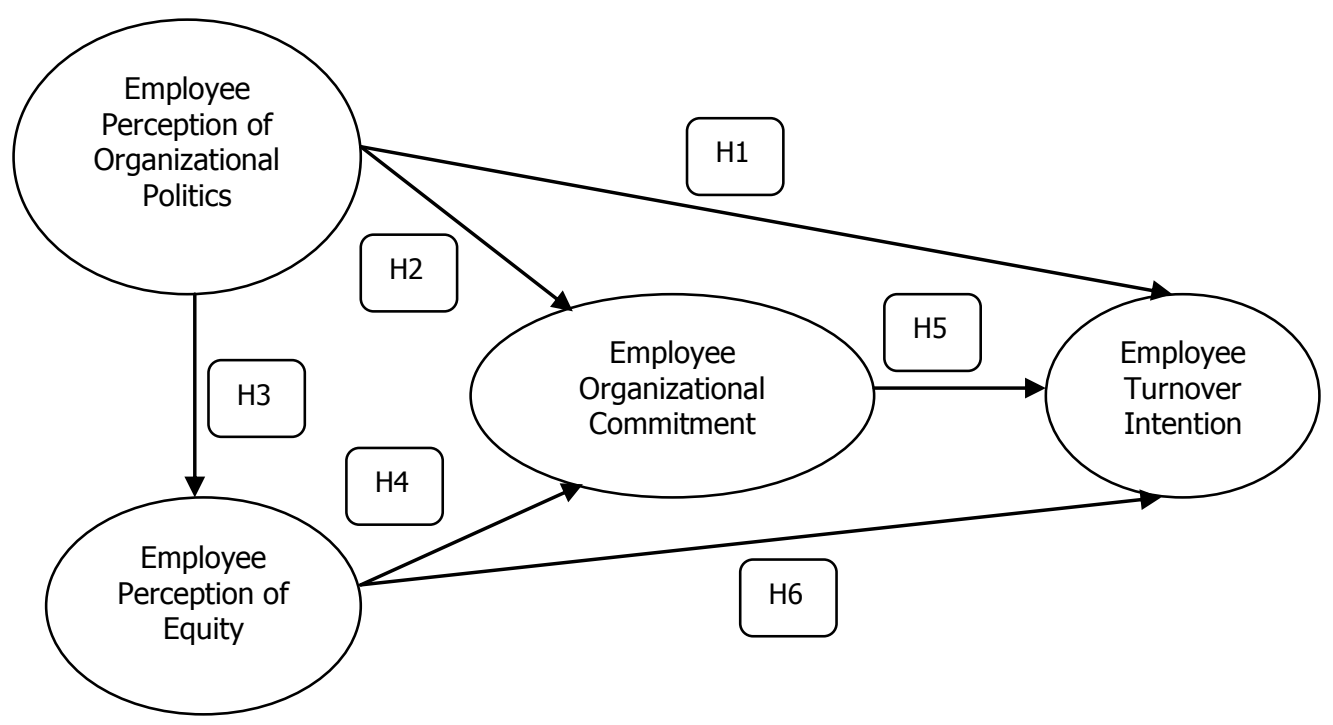

Figure 1: Conceptual framework

Previous empirical evidence has found perceived organizational politics to be positively related to turnover intentions in a significant way (Cropanzano, Howes, Grandey \& Toth, 1997; Randall, Cropanzano, Bormann \& Birjulin, 1999). Conceivably, when SMEs employees perceive their organization to be politically charged, they anticipate unfair treatment, manipulative decisions and actions at their workplace. As a result of this, their turnover intentions are likely to increase. Therefore, based on the abovementioned theoretical reasoning and prior empirical evidence, this study posits that:

H1: Employees' perceptions of organizational politics will have a significant positive effect on their turnover intentions in Zimbabwe's SME sector.

\section{Employee perception of organizational politics and organizational commitment}

From a theoretical perspective, justice judgment theory enumerate that when distributive and procedural rules are twisted to give some individuals unfair advantages or rewards, dissatisfaction sets in, morale is dampened because of perceived unfairness and consequently commitment to that organization is reduced (Randall et al., 1999). Empirical evidence also points to the fact that when political behavior within organization rises and workers feel that they have been treated unfairly, their organizational commitment decreases (Ferris et al., 2002; Valle \& Witt, 2001). A sizable number of recent studies seem to support the inverse relationship between employees' perceptions of organizational politics and organizational commitment (Vigoda-Gadot, Vinarski-Peretz \& Ben-Zion, 2003; Cater \& Zabka, 2009; Sieger et al., 2011). Conceivably, when SMEs employees perceive unfair treatment as a result of organizational politics at their workplace, they are likely to reduce their organizational commitment. Therefore, drawing from the theoretical reasoning and prior empirical evidence this study hypothesised that:
H2: Employees' perceptions of organizational politics will have a significant negative effect on their organizational commitment in Zimbabwe's SME sector.

\section{Employee perception of organizational politics and employee perception of equity}

Employees' perceptions of equity suggest that perceptions of fairness are a job related motivational base that can influence the behavioral and affective responses of job performers (Colquitt et al., 2001). Equity plays a very important role of motivating employees at workplace (Loi et al., 2006; Sieger et al., 2011). Employees make comparisons of their job inputs and outcomes. If employees perceive the ratio to be equal to that of others then a state of equity is said to exist. According to equity theory, if the ratio is unequal then the employees experience equity tension (Chan, Moir, Mestelman \& Muller, 1996).When employees see themselves as under rewarded, the resultant tension creates anger and when they see themselves as over rewarded then the consequential tension creates guilty (Janssen, 2001). In essence, perception of equity is related to the contribution rule of Justice Judgment theory. According to contribution rule of Justice Judgment theory, employees expect the ratio between effort spent and rewards received at work to be equitable. Job rewards on the other hand refer to inducements an employee may receive from an organization including money, desired job related responsibilities, esteem, status and social identity (Ranida, 2005). Inequity can be reflected as underrewarded or over-rewarded unfairness. According to the extant literature, a politically charged organization is characterized by, for instance, individuals manipulatively influencing decisions on rewards in their favor at the expense of others (Vigoda, 2000). Those unfairly disadvantaged will perceive inequity as they view their rewards to be not worthy their effort. In such a case organizational politics will be negatively related to 
employees' perceptions of equity. Prior empirical studies (e.g. Loi et al., 2006; Sieger et al., 2011) on large size organizations have supported the existence of a negative relationship between organizational politics and employees' perceptions of equity. Similarly, organizational politics in the SMEs sector is to be expected to be negatively related to employees' perceptions of equity. Therefore, deducing from Justice Judgment theory and prior studies the following hypothesis is postulated:

H3: Employees' perceptions of organizational politics will have a significant negative effect on their perceptions of equity in Zimbabwe's SME sector.

\section{Employee perception of equity and organizational commitment}

When employees put effort at their workplace and that effort is fairly rewarded, commitment to that organization will result (Loi et al., 2006; Sieger et al., 2011). Employees regard an outcome reward to be equitable when there is a balance between effort input and output (Almar, 2005). Such employees' perceptions of equity are likely to motivate and induce them to be loyal to that organization and eventually, long term organizational commitment result. The issue of equity which forms one of the basis of Justice Judgment theory has been used in numerous human resources studies to substantiate this reasoning (Sieger $e t$ al., 2011). In addition, prior empirical studies have supported a positive linkage between employees' perceptions of equity and organizational commitment (Lemons \& Jones, 2001; N'Goala, 2007). Similarly, when SME employees perceive their rewards to be fair or equitable when compared to their effort input or that of others, they are likely to be committed to that organization. Therefore, based on the aforementioned theoretical reasoning and empirical evidence, this study proposes that:

H4: Employees' perceptions of equity will have a significant positive effect on their organizational commitment in Zimbabwe's SME sector.

\section{Organizational commitment and employees' turnover intentions}

The relationship between organizational commitment and turnover intentions has been reviewed and examined extensively by researchers and academics over the decades (Meyer \& Allen, 1991; Cater \& Zabkar, 2009). Most of these studies argue that organizational commitment is an indication of employees' satisfaction with their workplace and as a result of this satisfaction, their turnover intentions are reduced. Drawing from Justice Judgment theory, if an employee perceives fairness at the workplace, he or she is unlikely to contemplate leaving the current organization to another. Furthermore, substantial empirical evidence has supported the negative linkage between organizational commitment and employee turnover intentions (Meyer, Stanley, Herscovitch and Topolnytsky, 2002; Meyer \& Herscovitch, 2001; Rhoades, Eisenberger \& Armeli, 2001). Accordingly, when SME employees are committed to their organization, because they feel motivated and fairly treated at their workplace, their turnover intentions are likely to be reduced. Therefore, drawing from the aforementioned arguments, this study hypothesizes that:

H5: Employees' organizational commitment has a significant negative effect on their turnover intentions in Zimbabwe's SME sector.

\section{Employee perception of equity and employee turnover intention}

A cross examination of the existing empirical human resources literature indicates that employees' perceptions of equity leads to low turnover intentions (Ranida, 2005). The reasoning is that when employees feel fairly treated, they feel motivated to stay in an organization and therefore, reduce their intention to leave (Griffeth, Hom \& Geatner, 2000; Price, 2001). This argument is also supported by the equity reasoning in the justice judgment theory. Accordingly, when SME employees perceive equity in their organization, they are likely to be pleased and become loyal to that organization (Solinger, Olffen \& Roe, 2008). In such a case they have no motivation to leave the organization hence, their turnover intention is reduced. Therefore, drawing from the aforementioned theory and empirical evidence, this study posits that:

H6: Employees' perceptions of equity will have a significant negative effect on their turnover intentions in Zimbabwe's SME sector.

\section{Research design and methodology}

\section{Sample and data collection}

The research was conducted with a survey method. A simple random probability sampling was used to select 300 SMEs because it gives all the subjects equal opportunity to be selected and hence avoiding bias. The Ministry of Small and Medium Enterprise in Zimbabwe provided the database because they have a list of all the Zimbabwean registered small and medium enterprises. Research assistants were engaged from the University of Zimbabwe to distribute and collect the questionnaires. The researchers distributed 300 questionnaires after making appointments with the respective SMEs owners or managers. SMEs employees who are not in the managerial positions were targeted to fill in the questionnaires. Non-managerial employees are those who are at the operational floor and who do the actual work such as welding, molding, painting and cooking food. This study sought to get information from non-managerial employees because turnover intention is reported to be high among them unlike their counterparts in managerial positions (Beauchamp \& Bowie, 2004; Carroll \& Buchholtz, 2006; Ferrell, Fraedrich \& Ferrell, 2008).

\section{Measurement instrument}

A questionnaire containing 42 measurement items was designed based on previous work for the current study. Adjustments were made in order to fit the purpose of the reflective scales used in the current research context. A fifteen-item scale used to measure employees' perceptions of organizational politics was adapted from the previous 
study by Kacmar, Bozeman, Carlson and Anthony (1999), while a seven-item scale to measure employees' perceptions of equity was adapted from Janssen (2001). Organizational commitment used a fifteen-item scale measure adopted from Meyer, Allen and Smith (1993) and Chinen and Enomoto (2004), while a five-item scale adapted from Wayne, Shore and Liden (1997) was used to measure employees' turnover intentions. All the measurement items were measured on a 5-point Likert-type scales that was anchored by $1=$ strongly disagree to $5=$ strongly agree to express the degree of agreement.

\section{Data analyses and results}

The research sample is described below. Then, the two-step procedure suggested by Anderson and Gerbing (1988) was applied to analyze the research data. That is, the accuracy of multi-item construct measures was assessed, followed by a test of the research model and hypotheses. In both data analysis stages, the current study mainly used StructuralEquation-Modeling (SEM) technique. The computation SEM software was AMOS 5.

\section{Sample description}

The study distributed questionnaires to different respective SMEs in Zimbabwe. Of the total of 300 questionnaires which were distributed, 253 were returned and out of these 253 questionnaires, only 250 were usable. This yielded a valid response rate of about $83.33 \%$. Descriptive statistics in Table 1 show the gender, age, marital status, and the number of employees in the company, respondents working experience, monthly salary, type of industries and the type of products produced.

\section{Table 1: Sample demographic characteristics}

\begin{tabular}{|c|c|c|}
\hline Gender & Frequency & Percentage \\
\hline Male & 190 & $76 \%$ \\
\hline Female & 60 & $24 \%$ \\
\hline Total & 250 & $100 \%$ \\
\hline Age & Frequency & Percentage \\
\hline$\leqq 30$ & 61 & $24,4 \%$ \\
\hline $31-60$ & 151 & $60,4 \%$ \\
\hline$\geqq 60$ & 38 & $15,2 \%$ \\
\hline Total & 250 & $100 \%$ \\
\hline Marital status & Frequency & Percentage \\
\hline Married & 100 & $40 \%$ \\
\hline Single & 150 & $60 \%$ \\
\hline Total & 250 & $100 \%$ \\
\hline Number of employees & Frequency & Percentage \\
\hline$\leqq 20$ & 69 & $27,6 \%$ \\
\hline $21-50$ & 35 & $14 \%$ \\
\hline$\geqq 51$ & 30 & $12 \%$ \\
\hline Total & 250 & $100 \%$ \\
\hline Participants working experience & Frequency & Percentage \\
\hline$\leqq 5$ years & 109 & $43,6 \%$ \\
\hline $5-10$ years & 86 & $34,4 \%$ \\
\hline$\geqq 10$ years & 55 & $22,0 \%$ \\
\hline Monthly salary in US dollar & Frequency & Percentage \\
\hline$\leqq \mathrm{US} \$ 200$ & 194 & $77,6 \%$ \\
\hline US\$200-US\$400 & 53 & $21,2 \%$ \\
\hline$\geqq \mathrm{US} \$ 400$ & 30 & $1,2 \%$ \\
\hline Total & 250 & $100 \%$ \\
\hline Industry & Frequency & Percentage \\
\hline Manufacturing & 159 & $63,6 \%$ \\
\hline Service & 91 & $36,4 \%$ \\
\hline Total & 250 & $100 \%$ \\
\hline
\end{tabular}

As indicated in Table 1, this study shows that males dominate the SMEs sector and constitute $76 \%$ of the workforce. The most active age group in SMEs is that between 31- 60 years which constitute $60.4 \%$ of the total workforce, followed by those below 30 years and then above 60 years, constituting $24.4 \%$ and $15.2 \%$ respectively. Employees who are single occupy $60 \%$ and the remainder is married. The profile indicates that more than three fifths of the participating SMEs employed 20 or fewer workers, while one fifth had a workforce between 21-50 employees and a minority of them had between 51-100 employees. Participants with less than 5 years work experience constituted 43 . $6 \%$ followed by those with between $6-10$ years work experience who constituted $34.4 \%$ and the 
remainder had above 10 years work experience. The majority of the participants consisting of $77,6 \%$ earned below US $\$ 200$ a monthly, while $21,2 \%$ earned between US\$200 - US\$400 and the remainder earned above US\$400. The study also indicated that the majority of the participants belonged to the manufacturing sector which occupied $63,6 \%$, while service sector occupied the remainder

\section{Measurement accuracy assessment}

Confirmatory factor analysis (CFA) was performed to examine the reliability, convergent and discriminant validity of the multi-item construct measures. Initial specification search led to the deletion of some of the items in the constructs scale in order to provide acceptable fit. Overall acceptable CFA model fit indices used in this study included: the $\chi^{2} /(\mathrm{df})$ (Chi-Square/Degree of Freedom) value equal to or less than 3.00, the CFI (Comparative Fit Index) value equal to or higher than 0,90, Tucker and Lewis Index (TLI) value equal to or higher than 0,90 , the Incremental Index of Fit (IFI) value equal to or higher than 0.90, and the Root Mean Square Error of Approximation (RMSEA) value equal to or less than 0.08 . Recommended statistics for the final overall model assessment showed an acceptable fit of the measurement model to the data, that is: $\chi^{2} /(\mathrm{df})=2,201$, $\mathrm{CFI}=0,923$, TLI $=0,917, \mathrm{IFI}=0,923$ and $\mathrm{RMSEA}=0,069$.

Loadings of individual items on their respective constructs are shown in Table 2.

The lowest value for individual item loadings for the research constructs is 0,692 . Therefore, all the individual item loadings exceeded the recommended value of 0,5 (Anderson \& Gerbing, 1988). This indicates that all the measurement instruments are acceptable and reliable since all the individual items converged well and with more than $60 \%$ of each item's variance shared with its respective construct.

Composite reliabilities (CR) and average variance extracted (AVE) for each construct were also computed using the formulae proposed by Fornell and Lacker (1981) i.e.

$\mathrm{CR} \eta=(\Sigma \lambda \mathrm{yi}) 2 /[(\Sigma \lambda \mathrm{yi}) 2+(\Sigma \varepsilon \mathrm{i})]$

where

$\mathrm{CR} \eta=$ Composite reliability, $(\Sigma \lambda$ yi $) 2=$ Square of the summation of the factor loadings; $\left(\sum \varepsilon i\right)=$ Summation of error variances.

$\mathrm{V} \eta=\Sigma \lambda \mathrm{yi} 2 /(\Sigma \lambda \mathrm{yi} 2+\Sigma \varepsilon \mathrm{i})$

where

$\mathrm{V} \eta=$ Average Variance Extracted (AVE); $\Sigma \lambda y i 2=$ Summation of the squared of factor loadings; $\Sigma \varepsilon i=$ Summation of error variances.

As indicated from the results shown in Table 2, the lowest obtained composite reliability (CR) value of 0,916 is well above the recommended 0.6 (Hulland, 1999), while the lowest obtained average variance extracted (AVE) value of 0,631 is also above the recommended 0.5 (Fraering \& Minor, 2006). This indicates that convergent validity was achieved and also this further confirms an excellent internal consistency and reliability of the measurement instruments used. Discriminant validity was established by ensuring that the average variance extracted (AVE) for each multi-item construct was greater than the shared variance between constructs (Nunnally \& Bernstein, 1994). As such, all pairs of constructs revealed an adequate level of discriminant validity (see Table 2). By and large, these results provided evidence for acceptable levels of research scale reliability.

\section{Research model assessment and research hypothesis testing}

The research model was estimated and the hypotheses testing done. All the research model fit statistics were within the acceptable ranges, i.e., $\chi^{2} /(\mathrm{df})=1,872, \mathrm{CFI}=0,944$, TLI $=0,940$, IFI $=0,945$, and RMSEA $=0,059$. The individual hypothesis testing results are also shown in Table 3 . The path coefficients for $\mathrm{H} 1, \mathrm{H} 2, \mathrm{H} 3, \mathrm{H} 4, \mathrm{H} 5$ and $\mathrm{H} 6$ are 0,290, $-0,811,-0,607,0,284,-0,416$ and $-0,223$ respectively. All hypothesis coefficients are significant at a confidence level ( $p$ value) of 0,001 . Therefore, these results provide support for all the proposed six hypotheses.

\section{Discussion and conclusions}

This study utilizes the Justice Judgment theory to provide a theoretical grounding for the conceptual framework that seeks to expound the effects of organizational politics on employees' turnover intentions in the SME business environment. More specifically, this study postulates that employees' perceptions of organizational politics significantly affect their turnover intentions in a positive way and negatively their organizational commitment and perceptions of equity while organizational commitment and perceptions of equity negatively impact on their turnover intentions. To confirm the proposed hypotheses of the research framework, data are collected from Zimbabwe's SME sector. The data analysis results support all the research hypotheses in this study. Overall, this provides support to the research propositions that employees' perceptions of organizational politics positively influence their turnover intentions and also negatively influence their organizational commitment and perceptions of equity in the SME setting.

Some interesting findings from this study are that, employees' perceptions of organizational politics influence organizational commitment more than they do on their perceptions of equity and turnover intentions. Furthermore, organizational commitment negatively influences turnover intentions more than employees' perceptions of equity and organizational politics do. This means that employees' perceptions of organizational politics have more influence on turnover intentions via organizational commitment than they directly do on the same or when mediated by employees' perceptions of equity. 
Table 2: Accuracy analysis statistics

\begin{tabular}{|c|c|c|c|c|c|c|c|}
\hline \multirow{2}{*}{\multicolumn{2}{|c|}{ Research Construct }} & \multicolumn{2}{|c|}{ Cronbach's Test } & \multirow{2}{*}{$\begin{array}{l}\text { C.R. } \\
\text { Value }\end{array}$} & \multirow{2}{*}{$\begin{array}{l}\text { AVE } \\
\text { Value }\end{array}$} & \multirow{2}{*}{$\begin{array}{c}\text { Shared } \\
\text { Variance }\end{array}$} & \multirow{2}{*}{ Factor Loading } \\
\hline & & Item-total & $\alpha$ value & & & & \\
\hline \multirow{13}{*}{$\begin{array}{l}\text { Perception of } \\
\text { Organizational } \\
\text { Politics (POP) }\end{array}$} & POP 1 &, 811 & \multirow{13}{*}{,967 } & \multirow{13}{*}{,967 } & \multirow{13}{*}{,694 } & \multirow[b]{13}{*}{,451 } &, 826 \\
\hline & POP 2 &, 845 & & & & & 856 \\
\hline & POP 3 & 856 & & & & & 866 \\
\hline & POP 4 & 843 & & & & & ,859 \\
\hline & POP 5 &, 812 & & & & &, 828 \\
\hline & POP 6 &, 785 & & & & & 801 \\
\hline & POP 7 & 830 & & & & & 847 \\
\hline & POP 9 & 816 & & & & &, 827 \\
\hline & $\begin{array}{l}\text { POP } 10 \\
\end{array}$ & 837 & & & & & 856 \\
\hline & POP 11 &, 785 & & & & & 801 \\
\hline & POP 13 & 806 & & & & &, 819 \\
\hline & POP 14 &, 831 & & & & & ,846 \\
\hline & POP 15 & ,777 & & & & & ,796 \\
\hline \multirow{16}{*}{$\begin{array}{c}\text { Organizational } \\
\text { Commitment (OC) }\end{array}$} & $\overline{\mathrm{OC} 1}$ & ,733 & \multirow{16}{*}{,959 } & \multirow{16}{*}{,960 } & \multirow{16}{*}{ 631 } & & ,753 \\
\hline & OC 2 & ,772 & & & & & ,784 \\
\hline & OC 3 & 801 & & & & &, 821 \\
\hline & OC 4 & ,794 & & & & &, 810 \\
\hline & OC 5 &, 754 & & & & & ,773 \\
\hline & OC 6 & ,787 & & & & & ,804 \\
\hline & OC 8 & ,793 & & & & & 819 \\
\hline & OC 9 &, 795 & & & & &, 812 \\
\hline & OC 10 & 772 & & & & &, 790 \\
\hline & OC 11 &, 756 & & & & &, 772 \\
\hline & OC 12 & ,791 & & & & & ,809 \\
\hline & OC 13 & 810 & & & & &, 829 \\
\hline & OC 14 &, 792 & & & & &, 803 \\
\hline & OC 15 & & & & & & \\
\hline & & ,724 & & & & & ,736 \\
\hline & & & & & &, 235 & \\
\hline \multirow{4}{*}{$\begin{array}{l}\text { Perception of Equity } \\
\text { (POE) }\end{array}$} & POE 1 & ,641 & \multirow{4}{*}{,909 } & \multirow{4}{*}{,916 } & \multirow{4}{*}{, 735} & \multirow[b]{4}{*}{,434 } & 692 \\
\hline & POE 5 & 859 & & & & & ,920 \\
\hline & POE 6 &, 832 & & & & & 908 \\
\hline & POE 7 & 856 & & & & & 889 \\
\hline \multirow{4}{*}{$\begin{array}{l}\text { Turnover Intention } \\
\text { (TI) }\end{array}$} & TI 1 & ,762 & \multirow{4}{*}{,918 } & \multirow{4}{*}{,921 } & \multirow{4}{*}{,746 } & \multirow[b]{4}{*}{, 515} & 803 \\
\hline & TI 2 & 863 & & & & &, 932 \\
\hline & TI 3 & 866 & & & & & 912 \\
\hline & TI 4 & ,767 & & & & & ,799 \\
\hline
\end{tabular}

Note: C.R.: Composite Reliability; AVE: Average Variance Extracted; S.V.: Shared Variance;

* Scores: 1 - Strongly Disagree; 3 - Neutral; 5 - Strongly Agree

Measurement CFA model fits: $\chi^{2} /(\mathrm{df})=2,201, \mathrm{CFI}=0,923$, TLI $=0,917, \mathrm{IFI}=0,923$ and $\mathrm{RMSEA}=0,069$ 
Table 3: Analysis results of the research structural model and related hypotheses

\begin{tabular}{ccc}
\hline Path Coefficients & Hypothesis & Factor Loading \\
\hline Organizational Politics (POP) $\rightarrow$ Turnover Intention (TI) & H1 & $0,290^{\mathrm{c}}$ \\
Organizational Politics (POP) $\rightarrow$ Organizational Commitment (OC) & H2 & $-0,811^{\mathrm{c}}$ \\
Organizational Politics (POP) $\rightarrow$ Perception of Equity (POE) & H3 & $-0,607^{\mathrm{c}}$ \\
Perception of Equity (POE) $\rightarrow$ Organizational Commitment (OC) & H4 & $0,284^{\mathrm{c}}$ \\
Organizational Commitment (OC) $\rightarrow$ Turnover Intention (TI) & H5 & $-0,416^{\mathrm{c}}$ \\
Perception of Equity (POE) $\rightarrow$ Turnover Intention (TI) & H6 & $-0,223^{\mathrm{c}}$
\end{tabular}

Note: ${ }^{a}$ significance level $<0,05 ;{ }^{b}$ significance level $<0,01 ;{ }^{\mathrm{c}}$ significance level $<0,001$;

Research structural model fits: $\chi^{2} /(\mathrm{df})=1,872, \mathrm{CFI}=0,944$, TLI $=0,940$, IFI $=0,945$, and RMSEA $=0,059$.

\section{Implications}

This study has academic and practical implications. On the academic front, two contributions are made. Firstly, an attempt was successfully made to apply the Justice Judgment theory in order to explicate important human resources management phenomena in the small business field. Secondly, this study examined an important issue in a neglected research context, that is, SMEs in a developing country of Southern Africa. Therefore, this study has expanded the existing literature on SME human resources management to developing countries.

As a practical contribution, the current study provides two strategic implications for owners or managers in the SMEs sector that focus on reducing the negative effects of organizational politics. Firstly, given that the employees' perceptions of organizational politics adversely impact on their organizational commitment, perceptions of equity and consequently increase their turnover intentions, managers in the SMEs sector are encouraged to adopt measures that are targeted at curbing the negative impact of organizational politics in order to reduce the consequential negative feelings and behavioral intentions from job strain suffered by employees. Such measures might include instituting a strict code of conduct at the workplace and ensuring that the code of conduct is understood, observed and enforced. Managers are also encouraged to reward desired behaviors that follow the code of conduct while punishing undesirable behaviors that promote negative organizational politicking at the workplace. Secondly, managers are encouraged to promote increased cooperation and team spirit among employees. Cooperation and teamwork tend to reduce the negative influence of organizational politics at workplace. Perhaps managers might consider rewarding cooperative behaviors and teamwork in order to motivate and strengthen employees' organizational commitment, perceptions of equity and consequently reducing their turnover intentions.

\section{Limitations and future research}

Although this study makes significant contributions to both academia and practice and also that due care was taken to achieve rigor, there are some limitations which open up avenues for further research. Firstly, the data were gathered from non-managerial employees in the SMEs sector. The results might be more informative if data from employees who hold managerial and non-managerial positions are to be compared. Therefore, subsequent studies might consider collecting data from these two sides for empirical investigation. Secondly, while this study focused on Zimbabwe, extending this study to other African countries is also another possible future research direction that might enable comparisons of results with the current study findings. Future research might also consider investigating the effects of employee perceptions of organizational politics on outcomes such as organizational citizenship behaviors and the actual employee turnover.

\section{References}

Almar, M.W. 2005. 'Equity sensitivity and negotiation behaviors: A look at Mexican exporters', Academy of Management Journal, 4(3): 1-16.

Anderson, J.C. \& Gerbing, D.W. 1988. 'Structural equation modelling in practice: A review and recommended two step approach', Psychological Bulletin, 103(3): 411-423.

Andrews, M.C., Witt, L.A. \& Kacmar, K.M. 2003. 'The interactive effects of organizational politics and exchange ideology on manager ratings of retention', Journal of Vocational Behavior, 62(2): 357-369.

Beauchamp, T.L. \& Bowie, N.E. 2004 Ethical theory and business. Upper Saddle River, NJ: Pearson Prentice Hall.

Carroll, A.B. \& Buchholtz, A.K. 2006. Business and society. Mason, $\mathrm{OH}$ : South-Western Thomson.

Carson, D. \& Gilmore, A. 2000. 'Marketing at the interface: Not "what" but "how"', Journal of Marketing Theory and Practice, 30(5): 122-133.

Cater, B. \& Zabka, C. 2009. 'Antecedents and consequences of commitment in marketing research services: The client's perspective', Industrial Marketing Management, 38(7): 785797. 
Chan, K., Mestelman, S., Moir, R. \& Muller, A. 1996. 'The voluntary provision of public goods under varying income distributions', Canadian Journal of Economics, 29: 54-69

Chinen, K. \& Enomoto, C. 2004. 'The impact of quality control circles and education on organizational commitment in northern Mexico assembly plants', International Journal of Management, 21(1): 51-62.

Chinomona, R., Lin, J., Wang, M. \& Cheng, J. 2010. 'Soft power and desirable relationship outcomes in Zimbabwe distribution channels', African Journal of Business, 11(2): 20-55.

Chinomona, R. \& Pretorius, M. 2011. 'SME manufacturers' cooperation and dependence on major dealers' expert power in distribution channels', South African Journal of Economics and Management Sciences, 12(2): 170-186.

Colquitt, J.A., Conlon, D.E., Wesson, M.J., Porter, C.O. \& Ng, K.Y. 2001. 'Justice at the millennium: A meta-analytic review of 25 years of organizational justice research', Journal of Applied Psychology, 86(3): 425-445.

Cropanzano, R., Howes, J.C., Grandey, A.A. \& Toth, P. 1997. 'The relationship of organizational politics and support to work behaviors, attitudes and stress', Journal of Organizational Behaviour, 18: 159-180.

Drory, A \& Vigoda-Gadot, E. 2010. 'Organizational politics and human resource management: A typology and the Israeli experience', Human Resource Management Review, 20(3): 194-202.

Ferrell, O.C., Fraedrich, J. \& Ferrell, L. 2008. Business ethics: Ethical decision making and cases. Boston, MA: Houghton Mifflin.

Ferris, G.R., Adams, G., Kolodinsky, R.W., Hochwarter, W.A. \& Ammeter, A.P. 2002. 'Peceptions of organizational politics: Theory and research indications'. In Miller, B.K., Rutherford, M.A. \& Kolodinsky, R.W. 2008. 'Perceptions of organizational politics: A meta-analysis of outcomes', Journal of Business Psychology, 22: 209-222.

Ferris, G.R. \& Kacmar, K.M. 1992. 'Perceptions of organizational politics', Journal of Management, 18: 93116.

Fornell, C. \& Larcker, D. 1981 'Structural equation models with unobservable variables and measurement error', Journal of Marketing Research, 18(1): 39-50.

Fraering, M. \& Minor, M.S. 2006. 'Sense of community: An exploratory study of US consumers of financial services', International Journal of Bank Marketing, 24(5): 284-306.

Griffeth, R.W., Hom, P.W. \& Geatner, S. 2000. 'A meta analysis of antecedents and correlates of employee turnover: Update, moderator tests and research implication for the next millennium', Journal of Management, 26(3): 463-489.
Hair, J.F., Babin, B.J., Anderson, R.E. \& Tatham, R.L. (Eds.). 2010. Multivariate data analysis. A global perspective. $7^{\text {th }}$ Edition. Prentice Hall.

Hulland, J. 1999. 'Use of Partial Least Squares (PLS) in strategic management research: A Review of four recent studies', Strategic Management Journal, 20(2): 195-204.

Janssen, O. 2001. 'Fairness perceptions as a moderator in the curvilinear relationships between job demands and job performance and job satisfaction', Academy of Management Journal, 44(5): 1039-1050.

Kacmar, M.K., Bozeman, D.P., Carlson, D.S. \& Anthony, W.P. 1999. 'An examination of the perceptions of organizational politics model: Replication and extension', Human Relations, 52: 383-416.

Lemons, M.A. \& Jones, A. 2001. 'Procedural justice in promotional decisions. Using perceptions of fairness to build employee commitment', Journal of Managerial Psychology, 16(4): 268-281.

Lind, E.A. 2001. 'Fairness heuristic theory: Justice judgments as pivotal cognitions in organizational relations'. In Greenberg, J. \& Cropanzano, R. (Eds.). Advances in organizational justice. Stanford, CA: Stanford University Press, pp. 56-88.

Loi, R., Hang-yue, N. \& Foley, S. 2006. 'Linking employees' justice perceptions to organizational commitment and intention to leave: The mediating role of perceived organizational support', Journal of Occupational and Organizational Psychology, 79(1): 101-120.

Lowe, R. \& Vodanovich, S.J. 1995. 'A field study of distributive and procedural justice as predictors of satisfaction and organizational commitment', Journal of Business and Psychology, 10(1): 99-114.

Meyer, J.P. \& Allen, N.J. 1991. 'A three-component conceptualization of organizational commitment', Human Resource Management Review, 1: 61-89.

Meyer, J.P., Allen, N.J. \& Smith, C.A. 1993. 'Commitment to organizations and occupation: Extension and test of a three component conceptualization', Journal of Applied Psychology, 78(4): 538-551.

Meyer, J.P. \& Herscovitch, L. 2001. 'Commitment in the workplace. Toward a general model', Human Resource Management Review, 11: 299-326.

Meyer, J.P., Stanley, D. J., Herscovitch, L. \& Topolnytsky, L. 2002. 'Affective, continuance and normative commitment to the organization: A meta-analysis of antecedents, correlates and consequences', Journal of Vocational Behavior, 61: 20-52

N'Goala, G. 2007. 'Customer switching resistance (CSR): The effects of perceived equity, trust and relationship commitment', International Journal of Service Industry, 18(5): $510-524$. 
Nunnally, J. \& Bernstein, I. 1994. Psychometric theory. $3^{\text {rd }}$ Edition. New York: McGraw-Hill.

Meyer, J.P., Allen, N.J. \& Smith, C.A. 1993. 'Commitment to organizations and occupation: Extension and test of a three component conceptualization', Journal of Applied Psychology, 78(4): 538-551.

Pfeffer, J. 1992. Managing with power: Politics and influence in organizations. Boston: Harvard Business School Press.

Price, J.L. 2001. 'Reflections on the determinants of voluntary turnover', International Journal of Manpower, 22(7): 600-624.

Ranida, B. 2005. 'Perceptions of organizational politics and cooperation as moderators of the relationship between job strains and intent to turnover', Journal of Managerial Issues, 1(1): 1-17.

Randall, M.L., Cropanzano, R., Bormann, C.A. \& Birjulin, A. 1999. 'Organizational politics and organizational support as predictors of work attitudes, job performance and organizational citizenship behavior', Journal of Organizational Behavior, 20: 159-174.

Rhoades, L., Eisenberger, R. \& Armeli, S. 2001. 'Affective commitment to the organization: The contribution of perceived organizational support', Journal of Applied Psychology, 86: 825-836.

Rosen, C.C., Chang, C.H., Johnson, R.E. \& Levy, P.E. 2009. 'Perceptions of the organizational context and psychological contract breach: Assessing competing perspectives', Organizational Behavior and Human Decision Process, 108(2): 202-217.
Sieger, P., Bernhard, F. \& Frey, U. 2011. 'Affective commitment and job satisfaction among non-family employees: Investigating the roles of justice perceptions and psychological ownership', Journal of Family Business Strategy, 2: 78-89.

Solinger, O.N., Olffen, W.V. \& Roe, R.A. 2008. 'Beyond the three component model of organizational commitment', Journal of Applied Psychology, 93(1): 70-83.

Valle, M. \& Witt, L.A. 2001. 'The moderating effect of teamwork perceptions on the organizational politics-job satisfaction relationship', The Journal of Social Psychology, 141(3): 379-388.

Vigoda, E. 2000. 'Organizational politics, job attitudes and work outcomes: Exploration and implications for the public sector', Journal of Vocational Behavior, 57: 326-347.

Vigoda-Gadot, E., Vinarski-Peretz, H. \& Ben-Zion, E. 2003. 'Politics and image in the organizational landscape', Journal of Managerial Psychology, 18: 764-787.

Walumbwa, F., Cropanzano, R. \& Hartnell, C.A. 2009. 'Organizational justice, voluntary learning behavior, and job performance: A test of the mediating effects of identification and leader-member exchange', Journal of Organizational Behavior, 30(8): 1103-1126.

Warner, J.C., Hegtvedt, K.A. \& Roman, P. 2005. 'Procedural justice, distributive justice: How experiences with downsizing condition their impact on organizational commitment', Social Psychology Quarterly, 68(1): 89-102.

Wayne, S.J., Shore, L.M. \& Liden, R.C. 1997. 'Perceived organizational support and leader member exchange: A social exchange perspective', Academy of Management Journal, 40(1): 82-111. 